it now is this recital of spray damage must be multiplied many times across the country. I believe the time has come when we must decide if we are to allow all plants susceptible to spray to vanish entirely. Are we to sacrifice all the beauty of roadside growth to good "road" housekeeping?

I would like to make the following suggestions:

1. Before the ultimate results of widespread spraying have been reached a comprehensive study of this problem should be made by governments, agricultural organizations, natural history organizations and scientists to determine what growth will be completely eliminated, and whether efforts should be made to protect certain trees, shrubs, flowers, etc.

2. In Montana there is a law applying to aeroplane spraying that requires the farmer and operator to fill out a report concerning conditions of spraying. Any complaints arising from the spraying should be made within 30 days. If such reports had to be made both the spray operator and those ordering the spraying would tend to use more care in their operations. Such reports wculd form a body of information to help study the whole spray situation.
3. Information should be made available to everyone through pamphlets accompanying weed killers, thrcugh farm and garden publications, University and Experimental Farm publications ,etc., of:

(a) The distances which spray will travel under different wind speeds, under various pressures, and from different heights of spraying.

(b) The various types of trees, shrubs, flowers, orchard and small fruits that are susceptible to spray. This information would alert the spray cperatcr to the damage he may be causing to native growth, and to nearby shelterbelts, orchards, borders and gardens.

4. Lists of plants particularly susceptible to weed killers should be available for the protection of the buying public, and seed companies and nurseries shculd list this information in their catalogues.

5. Study should continue to find pcssible antidotes or action to counteract the effects of spray on susceptible plants when we know they have been expcsed to spray.

Note: This timely article by one of our SNHS members is reprinted from The Gardener's Bulletin, Vol. 3, No. 2, April, 1964. Copies of it have also gone to the Saskatchewan Departments of Agriculture, Highways, and Municipal Affairs.

\title{
Plant Distributions on Kernen's Prairie, Saskatoon
}

by Graham B. K. Baines, University of Saskatchewan, Saskatoon

Kernen's Prairie consists of 320 acres of grassland which, despite the uitability of this land for cropping, have escaped cultivation and have hot experienced grazing since the 1930's. This may be the last sizeable emnant of the original grassland regetation of the glacial lake soils of he area. It is situated approximately ive miles east of Saskatoon.

This prairie, particularly when iewed from the air, appears as a mosaic of grassland interspersed with atches of shrub and Aspen Poplar Populus tremuloides). Such heteroseneity of vegetation reflects the ariations in soil and drainage conlitions which occur in the area. Durng the summer of 1963 the author, or his master's research, undertook a study of the distribution of plant species within the area in relation to these soil and drainage variations. This paper is a generalized account of the flora, with incidental observations of the fauna; further details of the vegetaticn can be obtained by referring to the University of Saskatchewan, M. Sc. thesis, Plant distribution on a Saskatchewan prairie in relation to edaphic and physiographic factors.

Slopes in the area are very slight and never exceed about two degrees yet this suffices to produce a pronounced change in habitat. The amount of soil moisture increases, as does the soil crganic matter, depth of soil and acidity as one proceeds downslope from the relatively dry 
central ridge. The most important factor in relation to the distribution of plant species in the area, appears to be soil moisture. On the ridge Speargrass (Stipa spartea var. curtiseta) and Northern Wheatgrass (Agropyron dasystachyum) are the dominant species. Farther downslope, the increased moisture promotes better growth of Rough Fescue (Festuca scabrella). As this grass increases in importance the Speargrass and Northern Wheatgrass decrease. Slender Wheatgrass (Agropyron trachycaulum) then appears and may reach its best development in areas similar to those in which Rough Fescue is at its best. On these lower slopes, patches of shrubs sometimes occur. The most important of these is Western Snowberry (Symphoricarpos occidentalis), which often forms dense stands. The leaf canopy developed by these shrubs reduces the sunlight penetrating to the ground. Light measurements taken under these shrubs indicated that the sunlight at groundlevel is often not more than ten percent of full sunlight. Certain changes take place in the grassland flora where these dense shrub canopies are present. Some species are totally excluded, e.g. Prairie Selaginella (Selaginella densa); others are reduced in number, e.g. Rough Fescue; while species such as Northern Bedstraw (Galium boreale) appear to develop just as well in the shade as in the open grassland. Though light may operate in this way as a selective agent, the factor chiefly responsible for determining which species grows where, and in what numbers, is soil moisture.

The conditions responsible for the development of dense shrub stands have not been elucidated. Under a given set of soil conditions and drainage it appears that either Fescue grasslands or shrubs may develop. It has been suggested that shrub stands develop where a pocket of waterbearing sand occurs beneath the soil surface. Borings to three feet showed no signs of such structures, though their possible occurrence at deeper levels could be significant. Perhaps shrub stands develop initially by chance, a single plant becoming established in the first instance. Subsequent vegetative development by underground stems would result in the formation of the circular to elliptic shrub patches which are characteristic of Kernen's Prairie.

Small depressional areas, probably glacial "kettles", occur in various portions of the prairie, both on the ridge and in low areas. These are conspicuous in their dominance by Wild Barley (Hordeum jubatum) and are drier, in late summer, than the adjacent lower slopes. It is suspected that this conditicn results initially from a soil which is much more compact than that of upland areas. Being denser, the soil is less permeable to water. This means that rainwater lies longer on the surface and more is lost by evaporation than from the lower slopes. These soils are also highly saline. Whereas upland species might well be suited to the prevailing moisture conditions, they are either unable to develop under the conditions of high salinity or at least are not able to compete successfully with Wild Barley and other lowland plants. Flcoding of these depressions in springtime may assist in preventing the establishment of upland species.

Although the present study was chiefly concerned with the distribution of common species, rare species are also of great interest. In this connection it is important to note the occurrence of several well-established bushes of Hoary Sagebrush (Artemisia cana). This is believed to be the first report of this species for the Saskatoon area. Other species common in the drier grassland of Saskatchewan but of rare occurrence in Kernen's Prairie, include Nuttall's (Atriplex nuttallii) and White Sage (Eurotia lanata). A single frond of Grape-fern (Botrychium sp.) was found growing beneath a dense canopy of Western Snowberry. Such a moist habitat is not unlike the usual haunts of this species. Why should it appear here so rarely?

Scme observations of the fauna in Kernen's Prairie were also made in 1963. Eggs in two Mallard nests, a crow and a Marsh Hawk nest all disappeared but young Sharp-tailed Grouse and Burrowing Owls were seen. Richardson's and Thirteenstriped Ground Squirrels were fairly numerous and there was evidence of an inhabited den of the Red Fox. 